ISSN: 2581-8341

Volume 05 Issue 02 February 2022

DOI: 10.47191/ijcsrr/V5-i2-35, Impact Factor: 5.825

IJCSRR@ 2022

www.ijesrr.org

\title{
Travelling in Macedonia in the Eve of the Greek Revolution European Travellers in Imathia
}

\author{
Emmanouel Xynadas ${ }^{1}$, Evi Psarrou ${ }^{2}$ \\ ${ }^{1} \mathrm{MA}, \mathrm{PhD}$, Ecclesiastical Academy of Vella of Ioannina -Greece \\ ${ }^{2} \mathrm{MA}, \mathrm{PhD}$, Ministry of Education- Greece
}

\begin{abstract}
The present paper refers to the phenomenon of "Travelling" in Macedonia during the pre-revolutionary years of the Greek War of Independence. The study focuses on the area of Imathia revealing- through the travel literature- important information in reference to the towns of Naoussa and Veroia shortly before the outbreak of the revolutionary movement in the area in the spring of 1822.
\end{abstract}

KEYWORDS: Greek Revolution, Imathia, Macedonia, Travelling accounts, Western travellers.

\section{INTRODUCTION}

The term "travelling" refers to a person's tours to a foreign place for the purpose of either leisure or the study of the people's way of life, customs and traditions, the history of the place, the study of the folk culture, religious ceremonies, politics, as well as demography, topography, the study of ancient sites and monuments etc.

\section{WESTERN TRAVELLERS IN OTTOMAN GREECE}

The first visits of western European travellers to Greece can be traced in the 15th and 16th century. Later on, in the 18th century, travellers visited Greece having a great interest in the classical antiquity. In the same century the burst of the phenomenon of travelling led to Greece a large number of travellers, archaeologists, historians, diplomats, physicists, doctors, scholars, writers, artists, naturalists, merchants. Apparently all of them wished to get in touch and get to know Greece, which was the cradle of European culture. In the same century the European Enlightenment movement also contributed to this development. Furthermore, the growing enthusiasm for Greece emerged as part of the "Grand Tour", a tour round Europe taken by young aristocrats for further educational purposes after completing their studies and before settling down to a more serious business. The route of the "Grand Tour" initially reached as far as Italy, however, gradually increased, including Greece, Asia Minor and more generally the territories of the Ottoman Empire.

\section{TRAVEL LITERATURE}

The various editions of the travel accounts contributed to the development of "travel literature". The term refers to the literature that typically records the travellers' experiences in some places and circumstances. As far as the "travel literature" in relation to Greece, the accounts include descriptions of the natural and historical site, the antiquities, the settlements and the landscape and in later years the economy, social and religious aspects of an "ancient country" that survived through centuries and eventually claimed its independence. The foreign visitors, through their various travels, gained personal experiences and knowledge about Greece whilst at the same time they contributed to the shaping of images of Greece by publishing their impressions of the country.

\section{TRAVELLERS AND PHILHELLENES}

It is worth mentioning that "travelling" promoted the development of "philhellenism", a prominent movement at the beginning of the 19th century which called upon international support to the Greek Revolution of 1821 . The philhellenes were touched by the cause of the Greeks and influenced many Western Europeans to join voluntarily the revolted Greeks and fight against the Ottoman Empire. This movement created a growing enthusiasm for the Greek Revolution amongst the American and European public opinion. In travel literature the ancient Greek heritage and the classical antiquity was idealized, whilst an increased enthusiasm and admiration for ancient Greece was apparent, elements which strengthened the philhellenic movement as both travellers and philhellenes considered themselves participants of the ancient Greek civilization. 


\section{International Journal of Current Science Research and Review}

ISSN: 2581-8341

Volume 05 Issue 02 February 2022

DOI: 10.47191/ijcsrr/V5-i2-35, Impact Factor: 5.825

IJCSRR@ 2022

www.ijesrr.org

Furthermore the philhellenes were influenced by Christianity, being themselves Christians as were the Greeks, acknowledged the latter's struggle for independence against a non-Christian conqueror that is the Ottoman Muslims and therefore the philhellenic movement strengthened even further. On top of that, the ideas of the Enlightenment and the proclaimed idea of liberty by French Revolution influenced and enhanced even more the philhellenic feelings of Europeans.

\section{TRAVELLERS AND PHILHELLENES IN MACEDONIA}

The presence and action of Philhellenes, who participated in the struggle for the Independence, can be traced mainly in the Peloponnese and Central Greece. There are also known cases that they visited the Ionian and the Aegean Islands. In Macedonia, however, things were different. Up to now there is no mention of the presence and participation of foreigners in the various revolutionary efforts. Nevertheless, Macedonia was visited by various foreign (European) travellers, who toured around the cities and villages as well as the Macedonian countryside. They recorded the habits of the people of Macedonia, its sites and monuments, its history and culture, as well as the social and public life of its people. Their experiences and impressions were the primary material for writing their accounts which were published in the following years.

During the period from 1770 to 1815 , Macedonia was visited by at least four travellers, two French and two Englishmen. These were the French Cousinéry ${ }^{1}$ and Pouqueville ${ }^{2}$ and the English Martin William Leake ${ }^{3}$ and Holland Henry. It seems that the Englishman Martin Leake toured Macedonia the most, because he visited thirteen different prefectures and collected data for at least two hundred and twelve locations. Next follows Francois Pouqueville, who visited twelve counties and recorded data from at least one hundred and fourteen different locations, while Marie Cousinéry stayed at eleven different counties and collected information from seventy-five visits round these counties. Finally, Henry Holland is the one who toured the least in the land of Macedonia as he passed through only two prefectures of Macedonia and recorded information from ten visits to the sights of the area.

Although there is no information about the exact reasons that led these travellers to visit Macedonia, there might be a close connection with their profession and service to their countries. Specifically, Leake was a diplomat appointed in 1806 as the head of the English diplomatic mission in Greece, whilst from 1808 to 1810 he became a follower diplomat of the English consul in Ioannina. As far as Pouqueville, he was consul general of France in Ioannina until 1815, and finally Cousinéry initially worked as a clerk at the French consulate in Thessaloniki, and later was appointed consul of France in the same city. Their status as diplomats, provided them the chance to tour and come to contact in many different places with several people, Ottoman Officers and Greek communal administrators.

All of them expressed a personal interest in highlighting the important cultural past of the region as well as to record the prevailing economic and social situation of the enslaved Greeks in the area of Macedonia. Therefore various information relevant to history, archaeology, political situation of the period, the social organization, the economic situation of the people, testimonies on ancient sites and monuments, folk culture, etc. is revealed through these travellers' accounts.

\section{THE TRAVELS OF COUSINÉRY, POUQUEVILLE AND LEAKE IN IMATHIA}

In particular, three out of the four aforementioned travellers passed through the area of Imathia, with the exception of Holland Henry. Specifically, Esprit - Marie Cousinéry was probably the first who visited the area. He visited the two largest centers of the province of Veroia, the city of Veroia and the city of Naoussa and provided us evidence in relation to the history of the area, the population, the archeological monuments, as well as the industrial production of the era, whilst in his descriptions he also referred to the rivers of Aliakmonas and Loudias. Special mention was also made for the famous wine of Naoussa, a well-known wine throughout the Ottoman Empire, which was consumed mostly in Thessaloniki and Serres, while its price was almost the double

\footnotetext{
${ }^{1}$ Cousinéry, Esprit Marie. Voyage dans la Macédoine, contenant des recherches sur l'histoire, la géographie et les antiquités de ce pays..., vol. I, Paris, Imprimerie royale, Imprimerie royale, MDCCCXXXI [=1831]. See also: https://eng.travelogues.gr/collection.php?view=317 (last accessed: 30/01/2022).

${ }^{2}$ Pouqueville, François-Charles-Hugues-Laurent. Grèce. Paris, Firmin Didot, MDCCCXXXV [=1835]. See also: https://eng.travelogues.gr/collection.php?view=23 (last accessed: 30/01/2022).

${ }^{3}$ Leake, William Martin. Travels in Northern Greece, vol. IV, Amsterdam, Adolf M. Hakkert, 1967. See also: https://eng.travelogues.gr/collection.php?view=422 (last accessed: 30/01/2022).
} 


\section{International Journal of Current Science Research and Review}

ISSN: 2581-8341

Volume 05 Issue 02 February 2022

DOI: 10.47191/ijesrr/V5-i2-35, Impact Factor: 5.825

IJCSRR@ 2022

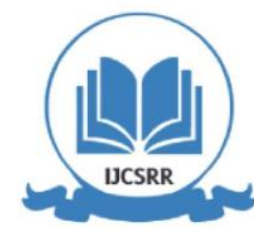

www.ijcsrr.org

compared to other wines in the region. The political situation of the province of Veroia, which was under the occupation of Ali Pasha of Ioannina, also aroused the traveler's interest and provoked his criticism.

The second Frenchman Francois Pouqueville reached many different places at the end of the 18th century and the beginning of 19th century. Amongst others he visited Imathia in 1806. Pouqueville started his route from Western Macedonia passed through Pieria Mountains and finally reached Imathia. During his journey in the area he initially visited the villages of Pieria Dratsko (Daskio), Kokova (Polydendri) and then the Monastery of Timios Prodromos. Pouqueville noted down many information relevant to the monastery, highlighting its historical past. Crossing Aliakmonas River, Pouqueville arrived in Veroia, which he described vividly, giving information both about the ancient Greek and the Christian past of the city, whilst he also described and commended on the natural beauties of the area. In addition, the traveler in his account provided information about Naoussa. Pouqueville was the one who brought to light information about the aftermath on the outcome of the failed uprising in Naoussa during the Greek revolution and the destruction of the city by the forces of Abut Lubut Pasha in April $1822^{4}$ whilst he also recorded the events that followed in Thessaloniki in May of the same year in relation to the victory of the Ottomans over the revolted Greeks of Naoussa. ${ }^{5}$

Finally, the most detailed account of all the above mentioned is Martin William Leake's who became the head of the British undercover mission to Greece in 1806. His tour in various parts of Greece took place in the same year, including Veroia and Naoussa. In Leake's writings there is important information about the geographical location of the two major centers of Imathia, namely Veroia and Naoussa, as well as the architecture of monuments in Veroia, population data, and furthermore data related to the economic and social life of the inhabitants of the two cities. However, it becomes apparent that the English traveler demonstrated special interest in the ancient monuments of Veroia, making great effort to exactly depict them as well as to transcribe and imprint part of the monuments' inscriptions. Finally, Leake also made a special reference to the prevailing political situation of the area at that time. He also referred to the administration of Ali Tepelenlis, the Pasha of Ioannina, under whose administrative sphere of influence was Veroia and Naoussa at that time. Although he did not have much to say about Naoussa, he referred extensively to Veroia's administration and economy whilst it becomes apparent that he had acquaintances with certain Ottoman administrators of the city. Finally, Leake recorded information about certain other places of Imathia such as Kastania and Koulakia (Campania), referring also to this locus as the seat of the bishop of Campania.

\section{CONCLUSION}

The above data, as well as other evident referring to many other Greek locations, prove that the European philhellenes and travellers were interested in the conquered and later on fighting Hellenism as a whole, regardless of geographical location. All the aforementioned travellers and many others, taking advantage of their professions, political, military, diplomatic positions, etc., visited different parts of the Ottoman Empire and afterwards with their writings made known to the European and the world public opinion the prevailing situation in the Ottoman-occupied areas. In addition, through travel literature many important data related to the cultural past and history of Greece were rescued and following transmitted to the next generations. Most importantly detailed descriptions of many monuments that no longer exist -as they were destroyed over the years- were recorded, depicted in drawings and the content of their inscriptions was preserved.

In conclusion, it could be noted that the travelling accounts is a major factor that contributed to the development of the philhellenic movement on the one hand, and on the other they are an invaluable and important source of information of the Greek past.

\section{REFERENCES}

1. Augustinou, O., Ideal Travels. Greece in French travel literature 1550-1821, Athens, 2003

2. Viggopoulou, I., "The traveling current in the 19th century. A cultural dialogue or a dialogue of cultures ", Comparison, 15 (2004), pp. 175-185.

\footnotetext{
${ }^{4}$ Xynadas, E., - Psarrou, E., (2021), “The Greek Revolution In Macedonia: Uprisings In Naousa And Veria In 1822,” International Journal of Arts Humanities and Social Sciences Studies, Volume 6 Issue 09, ॥ September 2021, pp. 52-55, Manuscript Id : 1179451503, (ISSN: 2582-1601), http://www.ijahss.com/vol6-issue9.html

${ }^{5}$ Xynadas, E., - Psarrou, E., (2021), "Celebrating an Ottoman Victory over the Revolted Greeks in 1822: The List of Revenues and Expenses", International Journal of Social Science And Human Research, Volume 04 Issue 10 October 2021, p.p. 2742-2746, ISSN(print): 2644-0679, ISSN(online): 2644-0695, IF-5.586, DOI : https://doi.org/10.47191/ijsshr/v4-i10-14 .
} 


\section{International Journal of Current Science Research and Review}

ISSN: 2581-8341

Volume 05 Issue 02 February 2022

DOI: 10.47191/ijesrr/V5-i2-35, Impact Factor: 5.825

IJCSRR@ 2022

www.ijjcsrr.org

3. Viggopoulou, I., "The Travelers in the 19th century. A multifaceted narrative ", History of Modern Hellenism 1770-2000, vol. 5, Athens, published by Ellinika Grammata, 2004, pp. 383-398.

4. Giakovaki, N., Towards Greece: a European itinerary of the emergence of Greece in the European consciousness, 17th18th century, (Doctoral dissertation submitted to the Department of History and Archeology of AUTh, Department of Modern and Contemporary History and Folklore), Thessaloniki, 2001.

5. Dimaras, K.Th., "Travel in Greece", Tours in Greece, Athens, 1968.

6. Koltsidas, A., The revolution and the destruction of Naoussa in 1822, Veria, 2010.

7. Moschou, D, "Travel and education. The Greece of Pouqueville (1770-1838) in the modern requirements of the educational practice ", Proceedings of the Hellenic Institute of Applied Pedagogy and Education, etc., e.g.

8. Batsaras, Porphyrios (Archim.), "Francis Pouqueville in Pieria in the year 1806", Chronicles of History and Culture of N. Imathia, 6 (Jul.-Sept. 2009), 7. [8] Andriotis, K. (2009). Early Travellers to Greece and their Modern Counterparts. Paper presented at the Tourist Experiences: Meanings, Motivations, Behaviours, April 1st - 4th 2009, University of Central Lancashire, Preston, UK.

9. Angelomatis-Tsougarakis, Helen, The Eve of the Greek Revival: British Travelers' Perceptions of the early ninetheeth century Greece, London/New York, Routledge, 1990.

10. Constantine, David, Early Greek Travellers and the Hellenic Ideal, Cambridge University Press, 1984.

11. Cousinéry, Esprit Marie. Voyage dans la Macédoine, contenant des recherches sur l'histoire, la géographie et les antiquités de ce pays..., vol. I, Paris, Imprimerie royale, Imprimerie royale, MDCCCXXXI [=1831]. See also: https://eng.travelogues.gr/collection.php?view=317 (last accessed: 30/01/2022).

12. Droulia, L., "The View of the Modem Greeks through the mid-sixteenth Century Travellers' Accounts", Balkan Studies 21 (1980), p. 275-285 http://www.ijahss.com/vol6-issue9.html

13. Leake, William Martin. Travels in Northern Greece, vol. IV, Amsterdam, Adolf M. Hakkert, 1967. See also: https://eng.travelogues.gr/collection.php?view=422 (last accessed: 30/01/2022).

14. Malakis, E., French travellers in Greece (1770-1820), Philadelphia 1925

15. Navari, L. (ed.), Greek Civilization through the Eyes of Travellers and Scholars from the Collection of Dimitris Contominas, Athens, Kotinos/Oak Knoll Press, 2003.

16. Pouqueville, François-Charles-Hugues-Laurent. Grèce. Paris, Firmin Didot, MDCCCXXXV [=1835]. See also: https://eng.travelogues.gr/collection.php?view=23 (last accessed: 30/01/2022).

17. Spencer, T., Fair Greece Sad Relic, literary philhellenism from Shakespeare to Byron, London 1954 (reprint Bath, 1974). Lord Elgin and the marbles, London 1967.

18. St. Clair, W., That Greece might still be free; the philhellenes in the war of independence, London 1972.

19. Tolias, G., "The Resilience of Philhellenism”, The Historical Review/La Revue Historique, vol. 13, 2016, pp.51-69

20. Tomkinson, J. (ed.), Travellers' Greece, Memories of an enchanted Land, Athens, Anagnosis, 2002.

21. Wallace, J., -Lambropoulos, V., Hellenism Philhellenism and Classical Reception: commemorating the 1821 Revolution, Clasical Receptions Journal, v. 13, issue 4, pp. 571-596.

22. Xynadas, E., - Psarrou, E., (2021), "Celebrating an Ottoman Victory over the Revolted Greeks in 1822: The List of Revenues and Expenses", International Journal of Social Science And Human Research, Volume 04 Issue 10 October 2021, p.p. 2742-2746, ISSN(print): 2644-0679, ISSN(online): 2644-0695, IF-5.586,

DOI : https://doi.org/10.47191/ijsshr/v4-i10-14.

23. Xynadas, E., - Psarrou, E., (2021), “The Greek Revolution In Macedonia: Uprisings In Naousa And Veria In 1822," International Journal of Arts Humanities and Social Sciences Studies, Volume 6 Issue 09, \| September 2021, pp. 52-55, Manuscript Id : 1179451503, (ISSN: 2582-1601 SJIF 2020: 7.662. http://dx.doi.org/10.29322/IJSRP.11.12.2021.p12052.

Cite this Article: Emmanouel Xynadas, Evi Psarrou (2022). Travelling in Macedonia in the Eve of the Greek Revolution European Travellers in Imathia. International Journal of Current Science Research and Review, 5(2), 590-593 